\title{
PENGARUH LIKUIDITAS DAN CORPORATE GOVERNANCE TERHADAP KINERJA PERBANKAN
}

\author{
Selviana Nuri Rahayu ${ }^{1}$, Hariyati ${ }^{2}$ \\ 1,2Universitas Negeri Surabaya, selviana.17080694039@mhs.unesa.ac.id; hariyati@unesa.ac.id
}

\begin{abstract}
ABSTRAK
Penelitian ini untuk mengetahui pengaruh likuiditas dan corporate governance terhadap kinerja keuangan perbankan. Populasi adalah perusahaan sektor perbankan yang terdaftar di Bursa Efek Indonesia tahun 2017-2019 dengan metode purposive sampling dan sampel berjumlah 43 perusahaan. Likuiditas diukur menggunakan Loan To Deposit Ratio (LDR) dan Loan To Asset Ratio (LAR), corporate governance menggunakan mekanisme corporate governance, dan Return on Assets (ROA) mengukur kinerja keuangan perbankan. Teknik analisis regresi linier berganda di bantu oleh SPSS. Loan To Deposit Ratio (LDR), Loan To Asset Ratio (LAR), komite audit, dan kepemilikan institusional tidak berpengaruh terhadap kinerja keuangan perbankan. Sedangkan kepemilikan manajerial dan dewan komisaris independen berpengaruh negatif terhadap kinerja keuangan perbankan. Likuiditas dan corporate governance berpengaruh secara simultan terhadap kinerja perbankan. Hasil penelitian ini dapat dijadikan acuan untuk perusahaan perbankan supaya lebih optimal meningkatkan kinerja keuangan. Hal tersebut karena menarik minat investor melakukan investasi terlebih pada perusahaan yang sudah mengimplementasikan good corporate governance dengan maksimal. Hal terpenting untuk memaksimalkan kinerja keuangan perbankan yaitu menjaga likuiditas, kepercayaan para nasabah dan penerapan mekanisme corporate governance.
\end{abstract}

Kata Kunci: Corporate Governance, Kinerja Perbankan Likuiditas

\begin{abstract}
This study is to find out the effect of liquidity and corporate governance on financial performance of banking. Using the population of banking sector companies listed on the Indonesia Stock Exchange 2017-2019 with a purposive sampling method and sample are 43 companies. Liquidity are measured using Loan To Deposit Ratio (LDR) and Loan To Asset Ratio (LAR), corporate governance used corporate governance mechanisms, and Return on Assets (ROA) measure financial performance of banking. Multiple liniear regression analysis techniques in the helped by SPSS. Loan To Deposit Ratio (LDR), Loan To Asset Ratio (LAR), audit committee, and institutional ownership have no effect on financial performance of banking. Meanwhile, managerial ownership and independent board of commissioners have a negative effect on financial performance of banking. The results obtained are liquidity and corporate governance have a simultaneously effect on performance of banking. The results of this study can be used as a reference for banking companies to optimize their financial performance. This is because it attracts investors to invest, especially in companies that have implemented good corporate governance optimally. The most important thing to maximize banking financial performance is to maintain liquidity, trust customers and implement corporate governance mechanisms.
\end{abstract}

Keywords: Liquidity, Corporate Governance, Financial Performance of Banking

Naskah diterima : 03-05-2021, Naskah dipublikasikan : 30-11-2021 


\section{PENDAHULUAN}

Sektor perbankan dinilai penting dalam pergerakan ekonomi Indonesia dengan tugas utamanya sebagai lembaga intermediasi. Perbankan dituntut untuk menumbuhkan rasa kepercayaan masyarakat dengan selalu meningkatkan efisiensi, stabilitas likuiditas, dan kualitas aset guna menarik investor. Perbankan dikatakan sehat dari kegiatan operasional dinilai dari kinerja keuangan perbankan. Husna \& Satria (2019) menyatakan meningkatnya nilai perusahaan linier dengan kinerja keuangan perbankan maka return yang diperoleh meningkat sehingga akan mensejahterakan pemegang saham. Untuk menilai kinerja perbankan dapat dengan menganalisis laporan keuangan dengan menghitung rasio keuangan. Pihak manajemen bank juga harus mampu mempertahankan laba yang diperoleh bank (Kasmir, 2012). Kinerja keuangan dinilai dengan profitabilitas yaitu dengan menganalisis Return on Assets Ratio (ROA) (Acar \& Temiz, 2017). ROA mengukur jumlah keuntungan yang bisa dihasilkan dengan menggunakan semua asetnya (Aprianingsih \& Yushita, 2016). Dengan arti lain nilai ROA meningkat maka bank mampu mengelola aset dan menghasilkan laba semakin baik dengan begitu kinerja bank dikatakan baik. Kinerja keuangan bank selain dipengaruhi oleh ROA juga dipengaruhi oleh banyak aspek yaitu likuiditas, efisiensi, kualitas aset dan kepekaan terhadap pasar (Cahyono \& Anggraeni, 2015).

Sektor perbankan harus memperhatikan manajemen likuiditas. Seperti kasus yang telah terjadi pada tahun 2008 krisis ekonomi pada Amerika Serikat mengakibatkan lembaga keuangan harus dilikuidasi dan bangkrut, begitu pula di Negara Indonesia tahun 2008 Bank Century alami likuiditas. Likuiditas bank yaitu mengacu pada kemampuan bank untuk memenuhi kewajibannya dalam menagih hutang jangka pendek (Kasmir, 2012). perbankan harus memiliki kas yang tersedia atau aset lancar lainnya yang dapat diubah menjadi uang tunai untuk memenuhi kewajiban jangka pendek (Muthoni et al., 2013). Sehingga jika perusahaan perbankan mengalami kasus dan atau krisis, bank sudah memiliki solusi sehingga tidak terjadi likuidasi. Menurut Romadloni \& Herizon (2015) Loan To Deposit Ratio (LDR) dan Loan To Asset Ratio (LAR) digunakan menilai rasio likuiditas. Penelitian Dewi et al., (2015) dan Arjuna (2020) menyatakan Loan To Deposit Ratio (LDR) dan Loan To Asset Ratio (LAR) secara signifikan terdapat pengaruh positif terhadap ROA. Berbeda dengan penelitian Suhita \& Mas'ud (2016) dan Liviawati et. al., (2018) yang menyatakan bahwa Loan To Deposit Ratio (LDR) dan Loan To Asset Ratio (LAR) tidak berpengaruh terhadap ROA.

Dalam pengelolaan likuiditas dilakukan dengan efisien dengan diterapkannya good corporate governance (Sugiyanto \& Setiawan, 2019). Fungsi corporate governance yaitu menjembatani hubungan antara stakeholders dengan perusahaan untuk memperhatikan kinerja dari mekanisme corporate governance A. S. Putra \& Nuzula (2017) diharapkan akan menghasilkan check and balance antara perumusan dan pelaksanaan kebijakan. Dalam penelitian Al-Janadi et al., (2013) agency theory mengatur corporate governance dengan memisahkan kepemilikan perusahaan dari kepengurusan. Dengan arti lain meminimalisir konflik antara pemilik perusahaan dengan manajemen. Secara khusus, masalah keagenan terkait dengan pemahaman apakah direktur dan manajer bertindak jujur dan memprioritaskan kepentingan pemegang saham (misalnya, memaksimalkan nilai perusahaan). Fakta nya, masalah keagenan dapat diperluas hingga mencakup pemangku kepentingan lain seperti klien dan kreditur. Nizam et al., (2019) kualitas manajemen dan efisiensi perusahaan menunjukkan akses agar keuangan perusahaan dapat mengalir dengan keberlanjutan kinerja bisnis perusahaan.

Dengan diterapkannya corporate governance yang baik dan benar maka perbankan dapat memanajemeni likuiditas. Dengan begitu, pemantauan kelebihan dana atau melanggar batas minimum pemberian kredit (BMPK) terkendali. Penyempurnaan kualitas penerapan mekanisme corporate governance yang baik diiringi dengan memanajemeni likuiditas berlaku untuk perbankan syariah dan konvensional. Dalam penelitian Laksana (2015) kepemilikan manajerial berpengaruh sedangkan dewan komisaris independen dan kepemilikan institusional 
tidak terdapat pengaruh terhadap kinerja, diukur menggunakan ROA. Sedangkan penelitian Istighfarin \& Wirawati, (2015) menyatakan kepemilikan institusional berpengaruh sedangkan dewan komisaris independen dan komite audit tidak memiliki pengaruh terhadap kinerja yang diproksikan ROA. Hasil penelitian Aryani, (2019) menyatakan komisaris independen tidak memiliki pengaruh sedangkan kepemilikan manajerial tidak berpengaruh terhadap kinerja diukur dengan ROA. Dalam penelitian Rimardhani, dkk (2016) kepemilikan institusional, dewan komisaris independen, dewan direksi, dan komite audit memiliki pengaruh yang signifikan terhadap ROA.

Berdasarkan fenomena dan persaingan yang ketat, penting bagi sektor perbankan untuk memperhatikan manajemen likuiditas dan mengimplementasikan mekanisme corporate governance yang baik dan benar agar menjaga kestabilan dan meningkatkan kinerja keuangan perusahaan. Penelitian sebelumnya dengan hasil yang tidak konsisten dan ketidaksesuaian antara teori dengan hasil penelitian. Peneliti ingin melakukan penelitian ulang dengan diperkuat kajian empiris. Maka, dilakukan penelitian ulang pengaruh likuiditas serta corporate governance terhadap kinerja perbankan. Likuiditas diproksikan Loan To Deposit Ratio (LDR) dan Loan To Asset Ratio (LAR). Sedangkan corporate governance diproksikan mekanisme governance yaitu dewan komisaris independen, komite audit, kepemilikan manajerial dan kepemilikan institusional.

\section{KAJIAN LITERATUR}

\section{The Liability Management Theory}

"Suatu bank mahir menata passiva yang dimiliki sehingga dapat menjadi likuiditas untuk melunasi penarikan Dana Pihak Ketiga (DPK) dan mampu memberikan pinjaman kepada nasabah" (Siahaan \& Asandimitra, 2016). Bank dinyatakan likuiditas yaitu ketika mampu melunasi atas penarikan DPK berupa simpanan nasabah, giro serta deposito (Choudhry, 2011). Dalam penelitian Zenios et al., (2007) juga menjelaskan bank memperoleh keuntungan dari pinjaman yang diberikan kepada nasabah dengan asumsi mendapatkan bunga. Ogbeifuna \& Akinola, (2018) menyatakan struktur asset memiliki peran penting dalam likuiditas perbankan dan selalu dipertimbangkan dengan baik guna meningkatkan penggalangan dana dari investor.

\section{Shift Ability Theory}

Di kalangan perbankan Amerika teori ini sudah digunakan sejak tahun 1940-an yaitu tentang aktiva bank yang data dipindahkan. "Likuiditas bank dinilai dari kemampuan bank memberikan pinjaman dengan asetnya ke pihak/orang lain dengan nilai yang diperkirakan dengan arti lain bank menaruh investasi pasar terbuka dalam jangka pendek dalam portofolio asetnya" (Siahaan \& Asandimitra, 2016). Hal ini dilakukan agar pada saat deposan menarik dananya, bank hanya perlu menjual investasinya dan kemudian mengembalikannya kepada deposan.

\section{Agency Theory}

Teori keagenan sebagai dasar perkembangan konsep corporate governance. Agency theory dipopulerkan oleh Jensen \& Meckling tahun 1976. Hamdani (2016:30) menjelaskan pemegang saham memiliki kepemilikan penuh atas saham dan membutuhkan manajemen perusahaan untuk memaksimalkan keuntungan pemegang saham Al-Janadi et. al. (2013) Pengelolaan operasional perusahaan dari Pemilik perusahaan diwenangkan kepada manajer, seperti membuat keputusan perusahaan atas nama pemilik perusahaan dan mengelola dana. Conflict interest atau dengan kata lain fungsi manajemen dibedakan dengan fungsi kepemilikan, karena fungsi manajemen mudah terpengaruh oleh konflik keagenan. 


\section{JURNAL AKUNTANSI, Vol. 10, No. 2, November (2021)}

\section{Pengembangan Hipotesis}

Bank memiliki kemampuan untuk melunasi hutang dan dapat memenuhi permintaan kredit atau pinjaman nasabah. Asumsi kredit atau pinjaman yang diberikan bank akan menghasilkan keuntungan bank. Keuntungan bank dari pendapatan bunga dari pinjaman oleh nasabah (Hidayati, 2015). Bank tersebut mengalami kerugian apabila bank tidak mampu memberikan kredit padahal telah terhimpun dana yang banyak. Romadloni \& Herizon (2015) teori menyatakan jika loan to deposit ratio menurun, maka persentase kenaikan total kredit lebih kecil daripada meningkatnya persentase total DPK. ROA bank berpengaruh menurun jika menurunnya keuntungan bank akibat peningkatan pendapatan lebih kecil daripada kenaikan biaya. Hal ini sejalan dengan teori The Liability Management yaitu bank dinyatakan likuiditas jika bank mampu melunasi atas penarikan DPK berupa simpanan nasabah, giro serta deposito dan pinjaman yang diberikan kepada nasabah dengan asumsi mendapatkan bunga sehingga bank memperoleh keuntungan dan ROA meningkat. Didukung hasil penelitian terdahulu Ali (2017); Ambarawati \& Abudanti (2018) dan Lubis, dkk (2019) menyatakan Loan To Deposit Ratio (LDR) secara signifikan terdapat pengaruh positif terhadap ROA.

\section{$\mathrm{H}_{1}$ : Loan To Deposit Ratio (LDR) berpengaruh positif terhadap Return On Assets (ROA)}

Memprediksi risiko kredit macet, total asset bank harus jauh lebih besar daripada pinjaman yang diberikan. Sebab, total asset perbankan dinilai semakin mampu membiayai pinjaman yang diberikan kepada nasabah dengan arti lain agar nilai Loan To Deposit Ratio semakin kecil (Gunawan, 2018). Dalam penelitian Miadalyni \& Dewi (2013) jika Loan To Deposit Ratio meningkat, artinya persentase kenaikan jumlah pinjaman disalurkan lebih banyak dari peningkatan persentase total asset bank. Hasilnya, pendapatan naik, alhasil laba meningkat, ROA juga meningkat.

\section{$\mathrm{H}_{2}$ : Loan To Asset Ratio (LAR) berpengaruh positif terhadap Return On Assets (ROA)}

Dalam penelitian Putra \& Wirawati (2013) menjelaskan agency theory mengatur antara pemilik perusahaan dan manajemen yang jika hal tersebut tidak diatur seringkali manajemen perilaku curang menyebabkan kerugian bagi pemilik perusahaan. Dalam membuat keputusan, manajer senantiasa berhati-hati, karena dari hasil keputusan memiliki pengaruh langsung terhadap saham yang dimiliki oleh manajer. Kepemilikan manajerial mempengaruhi kinerja perusahaan sejalan dengan penelitian Gugong et. al., (2014) dan Noviawan \& Septiani (2013). Manajemen akan bekerja secara optimal untuk meningkatkan kinerja perbankan mengingat pihak manajemen juga memiliki saham pada perusahaan. jika kepemilikan manajerial meningkat, maka kinerja keuangan perusahaan juga meningkat.

\section{$\mathrm{H}_{3}$ : Kepemilikan Manajerial (KM) berpengaruh positif terhadap Return On Assets (ROA)}

Besarnya dewan komisaris independen dengan kemahiran dan profesionalisme berbeda, akan menjadi penyebab yang kuat menurunnya kemampuan dewan komisaris dalam pengawasan khususnya bidang perbankan. Munculnya masalah pengambilan keputusan, komunikasi dan koordinasi. Didukung dengan penelitian Aprianingsih \& Yushita (2016) menyatakan besarnya Dewan komisaris independen berhubungan terbalik terhadap kinerja perusahaan.

$\mathrm{H}_{4}$ : Dewan Komisaris Independen (DKI) berpengaruh negative terhadap Return On Assets (ROA) 


\section{JURNAL AKUNTANSI, Vol. 10, No. 2, November (2021)}

Komite audit berupaya menaikkan kinerja keuangan industri perbankan, mengurangi perilaku buruk manajemen dan meningkatkan kepercayaan investor pada bank. Mengawasi pengendalian internal perusahaan dan aktivitas perusahaan merupakan tugas komite audit. Di bawah pengawasan pengendalian internal perusahaan oleh komite audit akan meminimalisir situasi di mana manajemen melakukan perilaku tidak sehat untuk keuntungan sendiri sehingga banyaknya komite audit dapat meningkatkan kualitas kinerja perusahaan. Sejalan dengan penelitian Anjani \& Yadnya (2017) yaitu banyaknya komite audit akan berpengaruh terhadap peningkatan kinerja perusahaan.

\section{$\mathrm{H}_{5}$ : Komite Audit (KA) berpengaruh positif terhadap Return On Assets (ROA)}

Meningkat kepemilikan institusional akan dapat mengurangi agency cost dengan menekan biaya keagenan, dengan cara kepemilikan institusional yang lebih besar dapat mengurangi konflik antara kreditor dan manajer. Sehingga konsentrasi kepemilikan institusi akan meningkatkan nilai perusahaan Aprianingsih \& Yushita (2016). Presensi Kepemilikan institusional baik artinya akan melakukan pengawasan dengan bersungguh-sungguh terhadap kinerja manajer. Akibatnya manajer dibatasi tidak melakukan perilaku oportunistic untuk memaksimalkan kepentingan pribadi seperti memanipulasi laporan keuangan yang akan berdampak pada kinerja keuangan perusahaan.

\section{$\mathrm{H}_{6}$ : Kepemilikan Institusional (KI) berpengaruh positif terhadap Return On Assets (ROA)}

Penjabaran diatas, digambarkan kerangka pikir teoritis variabel-variabel yang mempengaruhi kinerja keuangan perbankan, sebagai berikut.

\section{Liabilitas :}

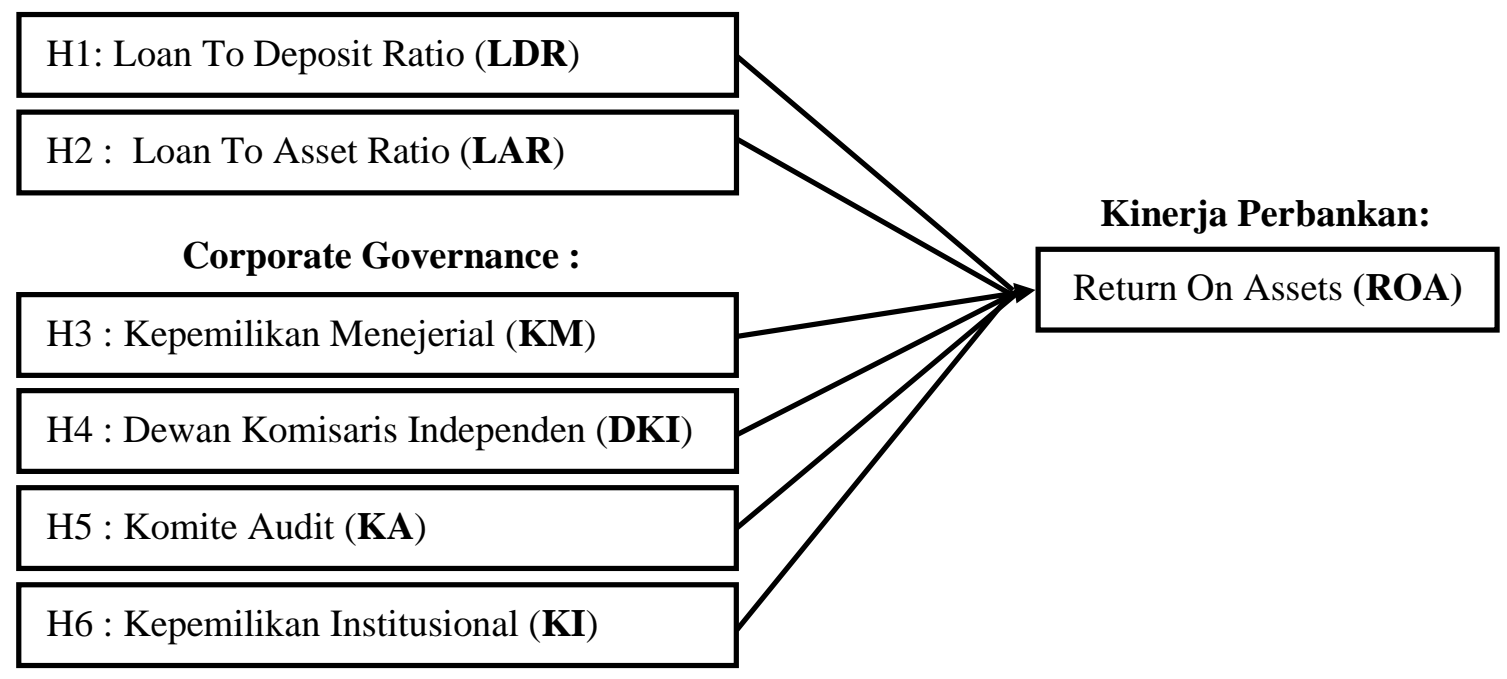

Gambar 1. Kerangka Pikir 


\section{JURNAL AKUNTANSI, Vol. 10, No. 2, November (2021)}

\section{METODE PENELITIAN}

Jenis penelitian yaitu penelitian kuantitatif. Data sekunder diambil dari situs Bursa Efek Indonesia (BEI) dan juga web resmi perusahaan berupa laporan tahunan perbankan tahun 20172019. Dan menggunakan software computer SPSS 25 untuk menganalisis data.

Populasi yang digunakan perusahaan perbankan yang terdaftar di BEI tahun 2017-2019. Metode teknik purposive sampling, yang memenuhi standar pengambilan sampel yaitu perusahaan berikut.

Tabel 1. Kriteria Pengambilan Sampel

\begin{tabular}{lc}
\hline \multicolumn{1}{c}{ Kriteria } & $\begin{array}{c}\text { Total } \\
\text { Perusahaan }\end{array}$ \\
\hline Perusahaan perbankan yang terdaftar di BEI & 45 \\
Tidak beroperasi secara berturut-turut di BEI tahun $2017-2019$ & $(2)$ \\
Jumlah memenuhi syarat sebagai sampel & $\mathbf{4 3}$ \\
\hline
\end{tabular}

Sumber: Data diolah penulis

\section{Likuiditas}

Likuiditas bank merupakan kemampuan bank dalam memenuhi kewajiban jangka pendeknya saat ditagih. Menurut (Kasmir, 2012: 316-319) mengukur likuiditas bank dengan rasio likuiditas yaitu:

1. Loan To Deposit Ratio (LDR): bank mengukur persentase total pinjaman yang diberikan dibagi total dana deposan atau pihak ketiga (SEBI No. 13/30/ dpnp-16 Desember 2011).

2. Loan To Asset Ratio (LAR): bank mengukur persentase total pinjaman yang dikreditkan dibagi banyaknya harta bank (Huwaidi, 2017).

\section{Corporate Governance}

Mekanisme corporate governance digunakan untuk mengukur corporate governance. Masing-masing dapat dihitung sebagai berikut.

1. Kepemilikan manajerial: mengetahui presentase kepemilikan saham pihak manajer kecuali komisaris independen dihitung dengan total saham pihak manajemen dibagi total saham yang beredar (Laksana, 2015).

2. Dewan komisaris independen: mengetahui persentase personil dewan komisaris memiliki sifat independen dihitung dengan total komisaris independen dibagi total dewan komisaris.

3. Komite audit: diukur dengan mengetahui total komite audit pada perusahaan (Mariana, 2016).

4. Kepemilikan institusional: mengetahui persentase nilai kepemilikan saham lembaga pemerintah, lembaga keuangan, lembaga asing dan badan hukum dihitung dengan cara total saham pihak institusi dibagi total saham yang beredar (Mariana, 2016).

\section{Kinerja Perbankan}

Menilai kinerja perbankan dengan rasio profitabilitas diproksikan Return On Asset (ROA). Surat edaran BI No. 13/24/DPNP dirumuskan persentase laba sebelum pajak dibagi total asset bank 


\section{Teknik Analisis Data}

Teknik Analisis regresi linear berganda di bantu software SPSS. Analisis berupa uji asumsi klasik meliputi uji normalitas, uji multikolinearitas, uji autokorelasi, uji heteroskedastisitas. Uji asumsi klasik dilakukan sebelum pengujian hipotesis untuk memastikan data penelitian memenuhi syarat dan layak untuk dianalisis. Syarat data layak diuji antara lain, terdistribusi secara normal, tidak heteroskedastisitas serta tidak multikolinieritas. Selanjutnya dilakukan analisis regresi linear berganda, uji koefisien determinasi $\left(R^{2}\right)$, uji simultan (uji f), dan Uji parsial (uji t). Persamaan regresi dalam penelitian ini sebagai berikut.

$$
Y=\alpha+\beta_{1} X_{1}+\beta_{2} X_{2}+\beta_{3} X_{3}+\beta_{4} X_{4}+\beta_{5} X_{5}+\beta_{6} X_{6}+e
$$

Keterangan:

$\begin{array}{ll}\mathrm{Y} & \text { :Return On Assets (ROA) } \\ \alpha & \text { :konstanta } \\ \beta_{1} \text { s/d } \beta_{5} & \text { :koefisien regresi variabel independen } \\ \mathrm{X}_{1} & \text { :Loan To Deposit Ratio (LDR) } \\ \mathrm{X}_{2} & \text { :Loan To Asset Ratio (LAR) } \\ \mathrm{X}_{3} & \text { :Kepemilikan manajerial } \\ \mathrm{X}_{4} & \text { :Dewan komisaris independen } \\ \mathrm{X}_{5} & \text { :Komite audit } \\ \mathrm{X}_{6} & \text { :Kepemilikan institusional } \\ \mathrm{e} & \text { :error }\end{array}$

\section{PEMBAHASAN}

\section{Uji Normalitas}

Pengujian ini menggunakan Kolmogorov - Smirnov Test dilakukan dua kali. Hasil signifikansi sebagai berikut.

Tabel 2. Hasil Uji Normalitas

\begin{tabular}{ll}
\hline $\mathbf{N}$ & Asymp. Sig. (2-tailed) \\
\hline 129 & 0,000 \\
114 & 0,200 \\
\hline
\end{tabular}

Sumber: Data diolah penulis

Uji normalitas yang pertama jumlah sampel 129 menunjukkan hasil data tidak terdistribusi normal. Menurut (Ghozali, 2018) apabila data terdistribusi tidak normal dilakukan tindakan outlier data, hasil uji normalitas yang kedua dengan data sampel 114 menunjukkan nilai sig 0,200 disimpulkan data telah terdistribusi normal.

\section{Uji Multikolinearitas}

Tabel 3. Hasil Uji Multikolinearitas

\begin{tabular}{lll}
\hline Variabel & Tolerance & VIF \\
\hline LDR & 0,432 & 2,316 \\
LAR & 0,491 & 2,035 \\
KM & 0,967 & 1,034 \\
\hline
\end{tabular}


JURNAL AKUNTANSI, Vol. 10, No. 2, November (2021)

\begin{tabular}{lll}
\hline Variabel & Tolerance & VIF \\
\hline DKI & 0,840 & 1,190 \\
KA & 0,939 & 1,064 \\
KI & 0,763 & 1,311 \\
\hline
\end{tabular}

Sumber: Data diolah penulis

Berdasarkan hasil uji dinyatakan bebas multikolinieritas

\section{Uji Autokorelasi}

Pengujian dengan metode Durbin Watson. Hasil dilihat pada tabel sebagai berikut.

Tabel 4. Hasil Uji Autokorelasi

\begin{tabular}{llllll}
\hline & N & K & Du & DW & 4-Du \\
\hline ROA & 114 & 6 & 1,8065 & 2,027 & 2,1935 \\
\hline
\end{tabular}

Sumber: Data diolah penulis

Berdasarkan data tabel diatas dapat disimpulkan bebas gejala autokorelasi.

\section{Uji Heteroskedastisitas}

Pengujian menggunakan uji glejser. Kesimpulan sebagai berikut.

Tabel 5. Hasil Uji Heteroskedastisitas

\begin{tabular}{lll} 
Variabel & Sig. & Keterangan \\
\hline LDR & 0,514 & \\
LAR & 0,974 & \\
KM & 0,071 & Nilai Sig lebih dari \\
DKI & 0,174 & Het maka Bebas \\
KA & 0,185 & \\
KI & 0,113 & \\
\hline
\end{tabular}

Sumber: Data diolah penulis

Koefisien Determinasi $\left(\mathbf{R}^{2}\right)$

Tabel 6. Hasil Uji Koefisien Determinasi

\begin{tabular}{llll}
\hline Model & $\mathbf{R}$ & R Square & Adjusted R Square \\
\hline 1 & 0,34 & 0,115 & 0,065 \\
\hline \multicolumn{3}{l}{ Sumber: Data diolah penulis }
\end{tabular}


Hasil uji koefisiensi determinasi bernilai 0,065 atau 6,5\%. Menunjukkan bahwa kinerja perbankan dapat dijelaskan oleh likuiditas dan corporate governance hanya 6,5\%, sementara 93,5\% sisanya dijelaskan faktor yang ada di luar penelitian.

\section{Uji Simultan (Uji F)}

Tabel 7. Hasil Uji F

\begin{tabular}{llll}
\hline Model & F & Sig. \\
\hline 1 & Regression & 2,307 &, $039^{\mathrm{b}}$ \\
& Residual & & \\
& & \\
Total & & \\
\hline
\end{tabular}

Sumber: Data diolah penulis

Nilai $\mathrm{F}$ yaitu 2,307 dan sig 0,039 nilai kurang dari 0,05 maka $\mathrm{H}_{1}$ diterima. secara simultan disimpulkan likuiditas serta corporate governance berpengaruh terhadap kinerja perbankan.

\section{Uji Parsial (Uji T)}

Tabel 8. Hasil Uji T

\begin{tabular}{lllllll}
\hline & \multicolumn{7}{c}{ Unstandardized Coefficients } & \multicolumn{2}{l}{$\begin{array}{l}\text { Standardized } \\
\text { Coefficients }\end{array}$} \\
\cline { 2 - 5 } Model & B & Std. Error & Beta & t & Sig. \\
\hline 1 & (Constant) & 0,021 & 0,014 & & 1,522 & 0,131 \\
& LDR (X1) & 0,017 & 0,011 & 0,213 & 1,542 & 0,126 \\
LAR (X2) & $-0,008$ & 0,017 & $-0,061$ & $-0,470$ & 0,639 \\
KM (X3) & $-0,075$ & 0,038 & $-0,185$ & $-2,000$ & 0,048 \\
DKI (X4) & $-0,032$ & 0,014 & $-0,229$ & $-2,305$ & 0,023 \\
KA (X5) & 0,001 & 0,001 & 0,089 & 0,946 & 0,346 \\
KI (X6) & $-0,005$ & 0,007 & $-0,082$ & $-0,786$ & 0,434 \\
\hline
\end{tabular}

Sumber: Data diolah penulis

Hasil uji $\mathrm{T}$ dilihat dari tabel diatas maka untuk menentukan pengaruh secara parsial variabel independen dengan $\mathrm{t}$ hitung dan signifikansi. Loan To Deposit Ratio (LDR) menghasilkan nilai sig 0,126 maka hipotesis pertama ditolak, Loan To Deposit Ratio (LDR) tidak memiliki pengaruh terhadap ROA. Loan To Asset Ratio (LAR) menghasilkan nilai sig 0,639 maka hipotesis kedua ditolak, Loan To Asset Ratio (LAR) tidak memiliki pengaruh terhadap ROA. Kepemilikan manajerial menghasilkan nilai sig 0,048 dan nilai koefisiensi 0,075 sehingga hipotesis ketiga diterima, disimpulkan Kepemilikan manajerial terdapat pengaruh negatif terhadap ROA. Dewan komisaris independen menghasilkan nilai sig 0,023 dan nilai koefisiensi -0,032 sehingga hipotesis keempat diterima, disimpulkan Dewan komisaris 
independen terdapat pengaruh negatif terhadap ROA. Komite audit menghasilkan nilai signifikansi 0,346 maka hipotesis kelima ditolak, kesimpulan Komite audit tidak terdapat pengaruh terhadap ROA. Kepemilikan institusional menghasilkan nilai sig 0,434 maka hipotesis keenam ditolak, kesimpulan kepemilikan institusional tidak terdapat pengaruh terhadap ROA.

\section{Pengaruh Loan To Deposit Ratio (LDR) terhadap Return On Assets (ROA)}

LDR tidak memiliki pengaruh terhadap ROA maka hipotesis pertama ditolak. Perbedaan antara hasil pengujian dengan hipotesis dipengaruhi oleh tingkat kredit macet, dana berlebih pada bank dan bank kekurangan dana. Sehingga dengan asumsi bahwa kredit yang disalurkan bank tidak sepenuhnya menghasilkan laba atau profit dari bunga kredit yang diterima bank. Faktor lain yaitu likuiditas terdapat implikasi risiko yaitu, bank memiliki dana yang berlebih yang disebut idle cash. Jika dana berlebih tersebut tidak dimanfaatkan untuk disalurkan kepada para kreditur akan menimbulkan pengorbanan tingkat bunga yang tinggi. Kemudian pada bank yang memiliki kekurangan dana akan mengalami kesulitan untuk membayar kewajiban jangka pendek. Hasil penelitian ini mendukung penelitian Liviawati et. al., (2018); Ayem \& Wahyuni (2017); Fajari \& Sunarto (2017); Suhita \& Mas'ud (2016) dan Pruwoko \& Sudiyatno (2013) LDR belum dapat menjamin kinerja perbankan. Ketika bank memberikan kredit secara berlebih dan mengharapkan akan mendapatkan keuntungan dari bunga kredit, terdapat risiko likuiditas rendah. Jika likuiditas tinggi, margin keuntungan tidak optimal.

\section{Pengaruh Loan To Asset Ratio (LAR) terhadap Return On Assets (ROA)}

LAR tidak memiliki pengaruh terhadap ROA maka dihipotesis kedua ditolak. Perbedaan antara hasil pengujian dengan hipotesis yang diteliti dapat disebabkan oleh faktor penambahan asset bank yang berasal dari deposan. Risiko likuiditas pada sisi asset ini dapat terjadi karena ketidakpastian deposan menarik pinjaman dan besarnya pinjaman yang akan ditarik. Faktor lain yang disebabkan LAR tidak berpengaruh dengan ROA yaitu terdapat kesenjangan dari data sampel yang diolah tahun 2017 hingga 2019 yaitu data pada ROA. Data minimum menunjukkan -0,023 pada tahun 2018 Bank Jtrust Indonesia Tbk dan data maksimum menunjukkan 0,040 pada tahun 2018 dan 2019 Bank Central Asia Tbk. sedangkan data sampel LAR nilai minimum 0,216 dan nilai maksimumnya 0,811. Masing-masing ROA dan LAR data sampel terpaut jauh sehingga mengakibatkan tidak terdapat pengaruh. Hasil penelitian ini sejalan dengan penelitian Ramadanti \& Meiranto (2015) risiko likuiditas dari sisi asset muncul akibat adanya kemacetan atau keterlambatan arus kas dari debitur.

\section{Pengaruh Kepemilikan Manajerial (KM) terhadap Return On Assets (ROA)}

Kepemilikan manajerial terdapat pengaruh negative terhadap ROA maka hipotesis ketiga diterima namun berpengaruh negative. Nilai kepemilikan manajerial tinggi maka, semakin rendah kinerja keuangan perusahaan. Keputusan dibuat oleh manajemen untuk keperluan diri sendiri guna memprioritaskan kemakmuran diri sendiri, perilaku manajer seringkali berbenturan dengan kepentingan kepemilikan, dan mencoba berperilaku curang seperti memanipulasi laporan keuangan agar kinerja keuangan dinilai meningkat dan mampu mensejahterakan pemegang saham alhasil berdampak buruk bagi keseluruhan perusahaan dan membuat buruk kinerja perbankan (Candradewi \& Sedana, 2016). Hasil penelitian ini mendukung penelitian Fadillah (2017); Laksana (2015) dan Jusoh et. al., (2013). 


\section{JURNAL AKUNTANSI, Vol. 10, No. 2, November (2021)}

\section{Pengaruh Dewan Komisaris Independen (DKI) terhadap Return On Assets (ROA)}

Dewan komisaris independen berpengaruh negative terhadap ROA maka hipotesis keempat diterima. meningkatnya nilai komisaris independen, maka semakin rendah ROA perusahaan. Jiwa kepemimpinan yang rendah sehingga didominasi oleh dewan direksi dan dewan komisaris independen kurang kompeten dalam pengawasan pencegahan kerugian perusahaan sehingga kinerja perbankan tidak mengalami peningkatan. Pada saat yang sama, biaya untuk komisaris independen terus berlanjut mengakibatkan penurunan laba. Sehingga banyaknya komisaris independen mengakibatkan menurunnya ROA perusahaan. Faktor lain dewan komisaris independen terdapat afiliasi dengan pihak direksi sehingga kinerja komisaris tidak independen dan tidak objektif. Maka banyaknya proporsi dewan komisaris independen berakibat kinerja keuangan perusahaan menurun. Hasil penelitian ini mendukung penelitian Fadillah (2017) dan Melia (2015).

\section{Pengaruh Komite Audit (KA) terhadap Return On Assets (ROA)}

Komite audit tidak terdapat pengaruh terhadap ROA maka hipotesis kelima ditolak. Perbedaan antara hasil pengujian dengan hipotesis yang diteliti dapat disebabkan oleh dewan komisaris membentuk komite audit ternyata berperan kurang maksimal dalam fungsi pengawasan terhadap proses pembuatan laporan keuangan dan mengawasi kegiatan internal perusahaan. Pengetahuan yang minim anggota komite audit dibidang keuangan dan tingkat independensi perusahaan menjadikan sebuah kelemahan auditor. Maka diharapkan komite audit bertindak lebih efektif. Komite audit yang dibentuk perusahaan hanya didasari kepatuhan terhadap peraturan. Hasil penelitian ini mendukung penelitian Putra \& Nuzula (2017); Rimardhani, dkk (2016); Raja (2016); Melia (2015) dan Istighfarin \& Wirawati (2015). Dengan ini disimpulkan komite audit tidak dapat mempengaruhi ROA.

\section{Pengaruh Kepemilikan Institusional (KI) terhadap Return On Assets (ROA)}

Kepemilikan institusional tidak terdapat pengaruh terhadap ROA maka hipotesis keenam ditolak. Seberapa besar struktur kepemilikan institusional tidak mempengaruhi kinerja perusahaan melainkan sesuai dengan teori agensi. Konflik ini merupakan konflik keagenan antar pemegang saham yang dapat memecah belah kepentingan bersama antara principal dengan agen. Konflik tersebut menyebabkan perusahaan akan lebih condong terhadap pemegang saham pengendali, sehingga kepentingan bersama tidak tercapai dan mengakibatkan ketidakseimbangan kinerja perusahaan. Hasil penelitian ini mendukung penelitian Hapsari (2015) dan Prasetyanto (2013).

Dari hasil penelitian disimpulkan likuiditas tidak mempengaruhi ROA, kredit yang disalurkan bank tidak sepenuhnya menghasilkan laba atau profit dari bunga kredit yang diterima bank. Faktor lain yaitu likuiditas terdapat implikasi risiko yaitu, bank memiliki dana yang berlebih yang disebut idle cash. Jika dana berlebih tersebut tidak dimanfaatkan untuk disalurkan kepada para kreditur akan menimbulkan pengorbanan tingkat bunga yang tinggi. Kemudian pada bank yang memiliki kekurangan dana akan mengalami kesulitan untuk membayar kewajiban jangka pendek. Risiko likuiditas pada sisi asset dapat terjadi karena ketidakpastian deposan menarik pinjaman dan besarnya pinjaman yang akan ditarik.

Dengan diterapkannya corporate governance yang baik dan benar maka perbankan dapat memanajemen kinerja keuangan perbankan sehingga mampu meningkatkan kinerja keuangan perusahaan (Hamdani, 2016:127). Dengan begitu, bank perlu memperhatikan likuiditas dengan tujuan pemantauan kelebihan dana atau melanggar batas minimum pemberian kredit (BMPK) terkendali (Putra \& Nuzula, 2017). Penyempurnaan kinerja perbankan dengan memperhatikan kualitas penerapan mekanisme corporate governance yang baik di iringi dengan memanajemen likuiditas berlaku untuk perbankan syariah dan konvensional. 


\section{PENUTUP}

\section{Simpulan}

Berdasarkan hasil pengujian, disimpulkan secara simultan likuiditas dan corporate governance mempengaruhi kinerja perbankan. Hasil uji parsial menunjukkan masing-masing variabel likuiditas tidak berpengaruh terhadap kinerja perbankan. Hal tersebut diakibatkan likuiditas terdapat terdapat implikasi risiko yaitu tingkat kredit macet, dana berlebih yang dimiliki bank dan bank kekurangan dana dan faktor lain yaitu terdapat selisih data yang terpaut jauh dari data sampel.

Untuk mengukur corporate governance menggunakan mekanisme corporate governance. hasil uji secara parsial yaitu kepemilikan manajerial dan dewan komisaris independen menunjukkan pengaruh negative terhadap kinerja perbankan. Namun, komite audit dan kepemilikan institusional tidak menunjukkan pengaruh terhadap kinerja perbankan.

\section{Saran}

Sebaiknya pihak manajemen bank harus lebih baik lagi dalam mengelola jumlah dana kredit yang diberikan kepada nasabah/konsumen agar Loan to Deposit Ratio (LDR) yang dihasilkan bank tetap berada dalam batas minimum dan maksimum yang telah ditetapkan Bank Indonesia (BI). Dan juga harus dapat mengelola deposits (dana pihak ketiga) serta keseluruhan dana (modal) yang telah dihimpun secara efektif dan efisien, karena pengelolaan kedua dana tersebut nantinya akan dapat mempengaruhi kemampuan bank dalam memperoleh laba dan secara langsung akan mempengaruhi nilai Return On Assets (ROA) yang dihasilkan bank.

Bagi seluruh perusahaan khususnya perusahaan perbankan, diharapkan menjadikan hasil penelitian ini sebagai wacana untuk lebih mengoptimalkan penerapan Good Corporate Governance dalam pengelolaan perusahaan. Karena tata kelola perusahaan yang baik akan menarik bagi para investor untuk melakukan investasi di perusahaan tersebut.

Nilai Adjusted R Square dalam penelitian ini tergolong rendah yakni 6,5\%. Hal ini menunjukkan 93,5\% masih terdapat variabel lain yang dapat mempengaruhi nilai perusahaan yang berada diluar penelitian ini. Oleh karena itu, disarankan kepada peneliti selanjutnya menambah variabel diluar penelitian ini. Penelitian ini masih memiliki keterbatasan yaitu, penelitian ini menggunakan data sekunder dengan metode penelitian kuantitatif, dan kemungkinan akan menghasilkan hasil analisis yang berbeda dengan menggunakan alat analisis lainnya yang lebih variatif untuk menguji variabel penelitian atau menggunakan metode kualitatif maupun campuran. Sampel yang digunakan juga hanya pada industri perbankan sehingga hasil penelitian tidak dapat digeneralisasi pada sektor lain.

\section{REFERENSI}

Acar, M., \& Temiz, H. (2017). Advertising effectiveness on financial performance of banking sector: Turkey case. International Journal of Bank Marketing, 35(4), 649-661. https://doi.org/10.1108/IJBM-03-2016-0036

Al-Janadi, Y., Rahman, R. A., \& Omar, N. B. (2013). The level of voluntary disclosure practices among public listed companies in Saudi Arabia and the UAE: Using a modified voluntary disclosure index. International Journal of Disclosure and Governance, 4(4), 2535. https://doi.org/10.1057/jdg.2011.19

Ali, M. (2017). Pengaruh Net Interest Margin (Nim), Biaya Operasional Terhadap Pendapatan Operasional (Bopo), Loan To Deposit Ratio (Ldr) Dan Non Performing Loan (Npl) Terhadap Return on Assets (Roa). Jurnal Riset Akuntansi Dan Keuangan, 5(2), 1-16. 
https://doi.org/10.17509/jrak.v5i2.7853

Ambarawati, I. G. A. D., \& Abundanti, N. (2018). Pengaruh Capital Adequacy Ratio, Non Performing Loan, Loan To Deposit Ratio Terhadap Return on Asset. E-Jurnal Manajemen Universitas Udayana, 7(5), 2410. https://doi.org/10.24843/ejmunud.2018.v07.i05.p04

Anjani, L. P. A., \& I Putu Yadnya. (2017). Pengaruh Good Corporate Governance Terhadap Profitabilitas Pada Perusahaan Perbankan Yang Terdaftar Di Bei. E-Jurnal Manajemen Universitas Udayana, 6(11), 5911-5940.

Aprianingsih, A., \& Yushita, A. N. (2016). Pengaruh Penerapan Good Corporate Governance, Struktur Kepemilikan, dan Ukuran Perusahaan Terhadap Kinerja Keuangan Perbankan. Jurnal Profita, 4(5), 1-16. https://eprints.uny.ac.id/31985/

Arjuna, I. P. A. (2020). Pengaruh Likuiditas, Kualitas Aset, Sensitivitas, dan Efisiensi Terhadap ROA Pada BPD Konvensional. Skripsi Program Studi Manajemen Sekolah Tinggi Ilmu Ekonomi Perbanas.

Aryani, K. H. (2019). Pengaruh Good Corporate Governance Terhadap Profitabilitas Perbankan Dengan Risiko Kredit Sebagai Variabel Intervening (Pada Perbankan Yang Terdaftar Di Bei Periode 2014-2016). Distribusi - Journal of Management and Business, 7(1), 63-80. https://doi.org/10.29303/distribusi.v7i1.45

Ayem, S., \& Wahyuni, S. (2017). Pengaruh Loan To Deposit Ratio, Capital Adequacy Ratio, Return on Asset Dan non Performing Loan Terhadap Return Saham. Jurnal Akuntansi, 5(1), 71. https://doi.org/10.24964/ja.v5i1.258

Cahyono, H. S. D., \& Anggraeni. (2015). Pengaruh likuiditas, kualitas aktiva, sensitivitas pasar, efisiensi, dan profitabilitas terhadap CAR pada bank devisa yang go public. Journal of Business and Banking, 5(1), 113-130. https://doi.org/10.14414/jbb.v5i1.383

Candradewi, I., \& Sedana, I. B. P. (2016). Pengaruh Kepemilikan Manajerial, Kepemilikan Institusional Dan Dewan Komisaris Independen Terhadap Return on Asset. E-Jurnal Manajemen Universitas Udayana, 5(5), 255207.

Choudhry, M. (2011). An introduction to banking: liquidity risk and asset-liability management. (Vol.30). John Wiley \& Sons.

Dewi, N. K. V. C., Cipta, W. dan, \& Kirya, I. K. (2015). Pengaruh LDR, LAR, DER dan CR Terhadap ROA. Journal Bisma Universitas Pendidikan Ganesha, 3(1), 1-10. https://ejournal.undiksha.ac.id/index.php/JJM/article/view/4655/3552

Fadillah, A. R. (2017). Analisis Pengaruh Dewan Komisaris Independen, Kepemilikan Manajerial Dan Kepemilikan Institusional Terhadap Kinerja Perusahaan Yang Terdaftar Di Lq45. Jurnal Akuntansi, 12(1), 37-52. http://jurnal.unsil.ac.id/index.php/jak

Fajari, S., \& Sunarto. (2017). Pengaruh CAR, LDR, NPL, BOPO terhadap Profitabilitas Bank (Studi Kasus Perusahaan Perbankan yang Tercatat di Bursa Efek Indonesia Periode Tahun 2011 sampai 2015). Prosiding Seminar Nasional Multi Disiplin Ilmu \& Call for Papers UNISBANK Ke-3, 3(Sendi_U 3), 853-862.

Ghozali, I. (2018). Aplikasi Analisis Multivariate Dengan Program IBM SPSS 25 (Kesembilan). Penerbit Undip.

Gugong, B. K., Arugu, L. O., \& Dandago, K. I. (2014). The Impact of Ownership Structure on the Financial Performance of Listed Insurance Firms in Nigeria. International Journal of Academic Research in Accounting, Finance and Management Sciences, 4(1), 409-416. https://doi.org/10.6007/ijarafms/v4-i1/698

Gunawan, B. A. (2018). Pengaruh Non Performing Loan (Npl) Dan Loan To Deposit Ratio 
(Ldr) Terhadap Profitabilitas Pada Perusahaan Perbankan Yang Terdaftar Di Bursa Efek Indonesia (Bei). In Jurnal Akuntansi: Kajian Ilmiah Akuntansi (JAK) (Vol. 5, Issue 1). https://doi.org/10.30656/jak.v5i1.504

Hamdani. (2016). Good Corporate Governance. Mitra Wacana Media.

Hapsari, A. H. (2015). Pengaruh Kepemilikan Saham Manajerial, Kepemilikan Institusional, Kebijakan Hutang, Kebijakan Dividen, Dan Ukuran Perusahaan Terhadap Nilai Perusahaan Manufaktur Di BEI. Skripsi. Universitas Negeri Yogyakarta.

Hidayati, L. N. (2015). Pengaruh Kecukupan Modal (CAR), Pengelolaan Kredit (NPL), dan Likuiditas Bank (LDR) Terhadap Probabilitas Kebangkrutan Bank (Studi pada Bank Umum Swasta Devisa yang tercatat di BEI tahun 2009-2013). Jurnal Ilmu Manajemen, 12(1), 38-50.

Husna, A., \& Satria, I. (2019). Effects of Return on Asset, Debt To Asset Ratio, Current Ratio, Firm Size, and Dividend Payout Ratio on Firm Value. International Journal of Economics and Financial Issues, 9(5), 50-54. https://doi.org/10.32479/ijefi.8595

Huwaidi, M. N. (2017). Analisis Pengaruh Risiko Likuiditas Terhadap Financial Performance Perbankan ( Studi Kasus pada Bank yang Terdaftar di Bursa Efek Indonesia Periode 2011-2015).

Istighfarin, D., \& Wirawati, N. G. P. (2015). Pengaruh Good Corporate Governance Terhadap Profitabilitas Pada Badan Usaha Milik Negara (BUMN). E-Jurnal Akuntansi Universitas Udayana Vol.13.No.2, 13(2), 564-581.

Jensen, M. C., \& Meckling, W. H. (1976). Theory of the firm: Managerial behavior, agency costs and ownership structure. Journal of Financial Economics, 3(4), 305-360.

Jusoh, M. A., Achmad, A. C., \& Omar, B. (2013). Managerial Ownership, Audit Quality and Firm Performance in Malaysia. International Journal of Arts and Commerce, 2(10), 4558.

Kasmir. (2012). Bank dan Lembaga Keuangan Lainnya. Rajawali pers.

Laksana, J. (2015). Corporate Governance Dan Kinerja Keuangan (Studi Kasus Pada Perusahaan Perbankan Yang Terdaftar Di Bei Periode 2008-2012). E-Jurnal Akuntansi Universitas Udayana, 11(1), 269-288.

Liviawati, Rajab, S., \& Gusmarilla. (2018). Pengaruh Capital Adequacy Ratio, Biaya Operasional Per Pendapatan Operasional, Non Performing Loan, dan Loan To Deposit Ratio Terhadap Return on Asset dan Return on Equity. PEKBIS (Jurnal Pendidikan Ekonomi Dan Bisnis), 10(2), 158-166. https://pekbis.ejournal.unri.ac.id/index.php/JPEB/article/viewFile/5804/5361

Lubis, M. S., Nasution, I. A., Mery, Jenvony, Yulia, V., Devika, V., \& Novera, V. (2019). Pengaruh Perputaran Aktiva, Perputaran Kas, dan Loan to Deposit Ratio (LDR) terhadap Return On Asset (ROA) pada Perbankan yang Terdaftar di Bursa Efek Indonesia pada Tahun 2013-2017. Owner Riset \& Jurnal Akuntansi, 3(2), 307. https://doi.org/10.33395/owner.v3i2.129

Mariana. (2016). Pengaruh Mekanisme Corporate Governance Terhadap Peringkat Obligasi yang Tercatat di Bursa Efek Indonesia Periode Tahun 2008-2010. Jurnal Akuntansi Fakultas Ekonomi UNESA, 7(2), 91-119.

Melia, A. (2015). Pengaruh Good Corporate Governance terhadap Kinerja Perusahaan pada Sektor Keuangan. Business Accounting Review, 3(1), 223-232. http://publication.petra.ac.id/index.php/akuntansi-bisnis/article/view/2763 
Miadalyni, P. D., \& Dewi, S. K. S. (2013). Pengaruh Loan To Deposit Ratio, Loan To Asset Ratio, Capital Adequacy Ratio Dan Kualitas Aktiva Produktif Terhadap Profitabilitas Pada Pt Bank Pembangunan Daerah Bali Kantor Pusat Denpasar. E-Jurnal Manajemen Universitas Udayana, 2(12), 248916.

Muthoni, J., Shimelis, H., \& Melis, R. (2013). Potato Production in Kenya: Farming Systems and Production Constraints. Journal of Agricultural Science, 5(5). https://doi.org/10.5539/jas.v5n5p182

Nizam, E., Ng, A., Dewandaru, G., Nagayev, R., \& Nkoba, M. A. (2019). The impact of social and environmental sustainability on financial performance: A global analysis of the banking sector. Journal of Multinational Financial Management, 49, 35-53. https://doi.org/10.1016/j.mulfin.2019.01.002

Noviawan, R. A., \& Septiani, A. (2013). Pengaruh Mekanisme Corporate Governance Dan Struktur Kepemilikan Terhadap Kinerja Keuangan. Diponegoro Journal of Accounting, 2(3), 744-753.

Ogbeifuna, I. E., \& Akinola, A. O. (2018). A Comparative Study of Asset-Liability Management Framework in the Banking Industry in Nigeria. International Journal of Governance and Development, 5.

Prasetyanto, P. (2013). Pengaruh Struktur Kepemilikan dan Kinerja Intellectual Capital terhadap Nilai Perusahaan. Skripsi Fakultas Ekonomika Dan Bisnis Universitas Diponegoro.

Pruwoko, D., \& Sudiyatno, B. (2013). Faktor-faktor yang mempengaruhi kinerja bank (Studi empirik pada industri perbankan di Bursa Efek Indonesia). Jurnal Bisnis Dan Ekonomi (JBE), 20(1), 25-39.

Putra, A. S., \& Nuzula, N. F. (2017). Pengaruh Corporate Governance terhadap Profitabilitas (Studi Pada Perusahaan Perbankan yang Terdaftar di Bursa Efek Indonesia Periode 20132015). Jurnal Administrasi Bisnis (JAB), 47(1), 103-112. administrasibisnis.studentjournal.ub.ac.id\%0A104

Putra, I. K. D. A., \& Wirawati, N. G. P. (2013). Pengaruh Kepemilikan Manajerial Terhadap Hubungan Antara Kinerja Dengan Nilai Perusahaan. E-Jurnal Akuntansi Universitas Udayana, 5(3), 639-651.

Raja, D. H. L. (2016). Pengaruh dewan komisaris, komisaris independen, komite audit terhadap profitabilitas pada perusahaan sektor property dan real estate yang terdaftar di bursa efek indonesia (bei) tahun 2009-2014. Jurusan Manajemen, Fakultas Ekonomi, Universitas Negeri Surabaya, 2(2), 139-146. https://jurnalmahasiswa.unesa.ac.id/index.php/jim/article/view/17531/15966

Ramadanti, F., \& Meiranto, W. (2015). Analisis Pengaruh Risiko Likuiditas Terhadap Profitabilitas Perusahaan Perbankan Di Indonesia. Diponegoro Journal of Accounting, 4(2), 447-456.

Rimardhani, H., Hidayat, R., \& Dwiatmanto, . (2016). Pengaruh Mekanisme Good Corporate Governance Terhadap Profitabilitas Perusahaan (Studi Pada Perusahaan Bumn Yang Terdaftar Di Bei Tahun 2012-2014). Jurnal Administrasi Bisnis S1 Universitas Brawijaya, 31(1), 167-175.

Romadloni, R. R., \& Herizon. (2015). Pengaruh likuiditas, kualitas aset, sensitivitas pasar, dan efisiensi terhadap Return On Asset (ROA) pada bank devisa yang go public. Journal of Business \& Banking, 5(1), 131-148. https://doi.org/10.14414/jbb.v5i1.384

Siahaan, D., \& Asandimitra, N. (2016). Pengaruh Likuiditas Dan Kualitas Aset terhadap Profitabilitas pada Bank Umum Nasional (Studi pada Bursa Efek Indonesia Periode 2010- 
2014). BISMA (Bisnis Dan Manajemen), 9(1), 1-12.

Sugiyanto, \& Setiawan, T. (2019). Pengaruh Likuiditas Profitabilitas Dan Good Corporate Governance Terhadap Nilai Perusahaan. Prosiding Seminar Nasional HUMANIS, 472490.

Suhita, M. D., \& Mas'ud, I. (2016). Pengaruh Risk Profile, Capital, dan GCG terhadap Profitabilitas Perbankan ( Studi Empiris Pada Bank Umum Konvensional yang terdaftar di BEI periode 2011-2014). Artikel Ilmiah Mahasiswa Fakultas Ekonomi Universitas Jember. http://repository.unej.ac.id/bitstream/handle/123456789/74067/MAYROSA DEWI SUHITA.pdf?sequence $=1$

Zenios, S. A., Ziemba, W. T., \& Eds. (2007). Handbook of Asset and Liability Management: Applications and case studies. Elsevier. 